\title{
Pengujian Mutu Sediaan Kapsul Minyak Hati Ikan Cucut Botol Dalam Beberapa Produk yang Beredar di Pasaran
}

\section{Quality Evaluation of Shark Liver Oil Capsule in Several Products on Market}

\author{
Triyadi Hendra Wijaya ${ }^{1,2^{*}}$, Tutus Gusdinar Kartawinata ${ }^{2}$, Ilma Nugrahani ${ }^{2}$ \\ ${ }^{1}$ Jurusan Farmasi, Fakultas Ilmu-Ilmu Kesehatan, Universitas Jenderal Soedirman, Purwokerto, Jawa Tengah, Indonesia \\ ${ }^{2}$ Sekolah Farmasi Institut Teknologi Bandung, Bandung, Jawa Barat, Indonesia
}

\begin{abstract}
ABSTRAK
Badan Standarisasi Nasional (BSN) melalui Standar Nasional Indonesia (SNI) Nomor 2730.1:2013 telah menetapkan standar mutu minyak hati ikan cucut botol yang terdiri dari uji sensoris, kadar air, kadar asam lemak bebas dan kadar skualen. Penelitian ini bertujuan untuk mengetahui mutu sediaan kapsul minyak hati ikan cucut botol yang beredar di pasaran. Pengujian mutu dilakukan sesuai dengan metode yang dirujuk SNI, adapun sampel uji berjumlah 6. Persyaratan nilai uji sensoris minimal 7, kadar air maksimal 0,3\%, kadar asam lemak bebas maksimal 1,5\% dan kadar skualen minimal 70. Berdasarkan hasil penelitian, semua sampel tidak memenuhi persyaratan kadar skualen, namun kesemuanya memenuhi persyaratan kadar asam lemak bebas. Salah satu sampel tidak memenuhi persyaratan kadar air dan uji sensoris.
\end{abstract}

Kata Kunci : minyak hati ikan cucut botol; kadar air; uji sensoris; kadar asam lemak bebas; skualen

\begin{abstract}
National standard agency of Indonesia has set the quality standard of shark liver oil through the Indonesian national standard which consists of sensory test, moisture content, free fatty acid as well as squalene concentration. The purpose of this study is to evaluate quality of shark liver oil capsule on market. As many as 6 samples were tested for the quality in accordance to SNI through organoleptic test $(<7)$, moisture content $(\max 0.3 \%$ ), free fatty acid content (max $1.5 \%$ ) and squalene concentration ( $\min 70 \%$ ). The results showed that the level of squalene in all samples do not meet the standard requirement, however all samples meet the free fatty acid content requirements. One sample does not fit the standard criteria in the term of organoleptic test and moisture content.
\end{abstract}

"Corresponding author

Keywords : shark liver oil; moisture content; sensory test; free fatty acid; squalene

Email: triyadlhendra_wijaya@yahoo.com

\section{PENDAHULUAN}

Indonesia adalah negara maritim yang sebagian besar daerahnya berupa kepulauan, sehingga banyak sekali memiliki kekayaan laut. Salah satu kekayaan kelautan yang berupa ikan adalah ikan hiu atau dikenal juga dengan nama ikan cucut. Indonesia tercatat sebagai salah satu negara yang memanfaatkan sumber daya ikan bertulang rawan (hiu dan pari) terbesar di dunia, dengan dugaan hasil tangkapan sebesar 105.000 ton pada tahun 2002 dan 118.000 ton pada 2003 . Indonesia juga memiliki kekayaan jenis hiu dan pari tertinggi di dunia (White et al., 2006).

Di Indonesia jumlah spesies ikan hiu mencapai 116 spesies dari 25 famili yang ditemukan di perairan Indonesia (Fahmi et al., 2013). Di perairan Indonesia terdapat ikan hiu yang dikenal memiliki hati dengan nilai ekonomis tinggi dengan berbagai spesies yang termasuk dalam famili Centrophoridae, Dalalatidae dan Squalidae. Spesies dari famili Centroporidae antara lain Centroporus squamosus, Centrophorus atromarginatus Garman, Centrophorus moluccensis, Centroporus cf lusitanicus, Centrophorus niaukang Teng, Deania cf calcea, Centroporus isodon. Spesies dari famili Dalalatidae yaitu Dalatias licha. Spesies dari famili Squalidae antara lain Squalus sp.1, Squalus sp.3, Squalus cf sp.C, Squalus sp.E (White et al., 2006).

Proses ekstraksi minyak hati ikan cucut botol pada umumnya dilakukan dengan merebus hati ikan cucut dalam wajan atau drum logam yang bagian atasnya terbuka tanpa mengendalikan suhu (Setiono, 2002). 
Selain cara tersebut biasanya nelayan langsung menjemur dibawah sinar matahari pada saat masih berlayar. Menurut Nurfauzi, et al (2014) jenis ikan cucut botol di Cilacap ada beberapa spesies dan nelayan tidak melakukan pemisahan secara khusus tetapi cenderung mencampur minyak hati ikan cucut botol dari berbagai spesies. Demikian juga dengan cara pengolahan hati ikan cucut botol berbagai macam cara ditempuh oleh nelayan untuk menghasilkan minyak sebanyak-banyaknya dalam waktu yang singkat selama mereka berlayar di laut. Oleh karena itu, tidak ada satu cara khusus yang dianut untuk mengolah hati ikan sampai dengan menghasilkan minyak. Minyak kemudian dikemas dalam bentuk kapsul untuk memudahkan konsumsi dan menutupi bau amis khas minyak ikan.

Minyak hati ikan cucut mengandung alkilgliserol (AKG) dan skualen. AKG dari minyak hati ikan cucut dapat sebagai terapi penunjang dalam pengobatan penyakit neoplastic dan sebagai penguat imunitas dalam penyakit infeksi (Pugliese et al., 1998). Minyak hati ikan cucut digunakan sebagai pengobatan alami untuk penguat imunitas, perlindungan jantung dan sebagai bahan antiageing. Penggunaan ini berkaitan dengan jumlah AKG yang banyak (22\%) yang diperoleh dari minyak hati ikan cucut (Debouzy et al., 2008). Alkilgliserol dan derivat metoksi yang ada di dalam minyak hati ikan cucut menunjukan efek apoptosis atau nekrosis sel pada sel line karsinoma prostat dan payudara (Krotkiewski et al., 2003). Skualen merupakan triterpen hidrokarbon (C30H50) yang mempunyai beberapa khasiat terhadap kulit yaitu emolient, antioksidan, dan aktivitas anti tumor (Huang et al., 2009). Skualen dapat digunakan sebagai adjuvant vaksin, menstimulasi respon imun dan meningkatkan respon pasien terhadap vaksin (Fox, 2009). Skualen dalam bentuk tunggal atau campuran dengan skualan dapat digunakan untuk pengobatan lokal akibat terbakar (Ogawa dan Doi, 1996).

Produk minyak hati ikan cucut botol yang paling banyak beredar adalah dalam bentuk kapsul. Produk ini dijual di apotek, toko herbal maupun toko online. Harga bervariasi mulai dari 400 sampai dengan $3000 \mathrm{rupiah} / \mathrm{kapsul}$. Produk minyak hati ikan cucut botol yang sudah beredar di pasaran ada yang sudah berijin dan belum berijin Badan Pengawas Obat dan Makanan (BPOM). Konsumen pada umumnya tidak memperhatikan masalah legalitas produk, hal ini terbukti dengan lakunya produk yang belum berijin BPOM.

BPOM melalui Keputusan Kepala BPOM RI No.HK.00.05.52.4040 Tahun 2006 tentang kategori pangan telah menetapkan karakteristik dasar minyak hati ikan cucut botol. Karakteristik dasar ini meliputi kadar asam lemak bebas $0,3 \%$, kadar skualen tidak kurang dari $70 \%$ dan kadar air tidak lebih dari 0,3\%. Badan Standarisasi Nasional (BSN) melalui Standar Nasional Indonesia (SNI) 2730.1:2013 juga telah menetapkan spesifikasi minyak hati ikan cucut botol mentah yang meliputi uji sensori minimal 7 , kadar asam lemak bebas maksimal 1,5\%, skualen minimal $70 \%$ dan kadar air maksimal $0,3 \%$.

Karakteristik dasar dan SNI mengenai spesifikasi minyak hati ikan cucut botol adalah untuk menetapkan standar kualitas minyak. Kualitas minyak yang rendah akan berdampak pada kesehatan orang yang menggunakan minyak tersebut. Kadar asam lemak bebas yang tinggi karena proses pemanasan menggunakan suhu tinggi pada saat ekstraksi akan menyebabkan menurunnya kualitas minyak dan memicu peningkatan kadar Low Density Lipoprotein $(L D L)$ atau kolesterol jahat. Kolesterol ini menyebabkan penyakit pada jantung dan pembuluh darah.

Skualen merupakan senyawa yang menjadi komponen utama minyak hati ikan cucut botol dan menjadikan minyak ini bernilai jual tinggi. Kadar skualen yang kurang dari $70 \%$ mengindikasikan dalam minyak tersebut lebih banyak komponen lain seperti asam lemak jenuh dan tak jenuh, skualan dan komponen senyawa lainnya. Jika asam lemak jenuh terlalu banyak juga akan memicu peningkatan kolesterol dalam tubuh.

Berdasarkan potensi sumber daya laut berupa tersedianya spesies ikan cucut botol yang melimpah di Indonesia, beragamnya produk minyak hati ikan cucut botol yang beredar di pasaran, karakteristik dasar yang telah ditetapkan BPOM, spesifikasi yang telah ditetapkan oleh BSN serta bahaya yang ditimbulkan oleh minyak hati ikan cucut botol kualitas rendah maka peneliti merasa penting untuk melakukan penetapan karakteristik dasar atau pengujian kualitas sediaan kapsul minyak hati ikan cucut botol yang beredar di pasaran.

\section{METODE}

\section{Bahan}

Sampel minyak hati ikan cucut botol yang dibeli di apotek (1 merek produk), toko herbal (2 merek produk) dan toko online (3 merek produk), etanol (Merck), dietil eter (Smart Lab), $\mathrm{NaOH}$ (Merck), $\mathrm{NaCl}$ (Merck), air suling bebas $\mathrm{CO}$, indikator fenolftalein, akuades, KOH (Merck), baku pembanding skualen 97\% (Merck) dan gas nitrogen. 


\section{Alat}

Tabung reaksi, cawan porselin volume $35 \mathrm{ml}$, alat penjepit/tang, desikator, pipet tetes, neraca analitik, oven vakum, selubung pemanas basah (water bath), pendingin refluk/kondensor, labu alas bulat, corong pisah bertutup, gelas ukur dan labu takar.

\section{Prosedur Kerja}

Prosedur kerja merujuk pada prosedur kerja yang disarankan pada SNI No.2730 1-2013 mengenai spesifikasi minyak hati ikan cucut botol mentah.

\section{Uji Sensoris (SNI 2346:2011)}

Pengujian sensoris merupakan cara pengujian menggunakan indera manusia sebagai alat utama untuk menilai mutu produk perikanan yang sudah mengalami proses pengolahan. Uji sensoris ini menggunakan uji skor (scoring test) dan menggunakan 30 panelis non standar yang memenuhi syarat. Metode ini dalam menentukan tingkatan mutu berdasarkan skala angka 1 (satu) sebagai nilai terendah dan angka 9 (sembilan) sebagai nilai tertinggi dengan menggunakan lembar penilaian. Penilaian contoh yang diuji dilakukan dengan cara memberikan nilai pada lembar penilaian sesuai dengan tingkatan mutu produk. Uji sensoris minyak hati ikan cucut botol meliputi warna, kekeruhan dan bau. Data yang diperoleh dari lembar penilaian ditabulasi dan ditentukan nilai mutunya dengan mencari hasil rerata pada setiap panelis pada tingkat kepercayaan 95\%.

\section{Penentuan Kadar Air (SNI 01-2354.2-2006)}

Penentuan kadar air menggunakan metode analisa gravimetri yang didasarkan pada penimbangan atau berat. Oven vakum yang akan digunakan terlebih dahulu dikondisikan pada suhu 95-1000C dan tekanan udara tidak lebih dari $100 \mathrm{mmHg}$ hingga mencapai kondisi stabil. Cawan kosong dimasukkan ke dalam oven vakum minimal 2 jam. Cawan kosong tersebut dipindahkan menggunakan tang ke dalam desikator sekitar 30 menit sampai mencapai suhu ruang dan timbang bobot kosong (A). Sampel minyak dimasukkan sebanyak $\pm 2 \mathrm{~g}$ ke dalam cawan (B). Cawan yang telah diisi dengan contoh dimasukkan ke dalam oven vakum pada suhu 95-100C dengan tekanan udara tidak lebih dari $100 \mathrm{mmHg}$ selama 5 jam. Pindahkan cawan dengan menggunakan alat penjepit ke dalam desikator selama \pm 30 menit kemudian ditimbang $(C)$. Lakukan pengujian minimal duplo (dua kali)

Rumus : $\quad \%$ kadar air $=\frac{\mathrm{B}-\mathrm{C}}{\mathrm{B}-\mathrm{A}} \times 100 \%$
Penentuan Kadar Asam Lemak Bebas (dihitung terhadap asam arakidonat)

Timbang seksama lebih kurang 5 gr zat, larutkan dalam labu yang berisi $25 \mathrm{ml}$ campuran sama banyak etanoleter dan telah dinetralkan dengan fenolftalein dengan kalium hidroksida $0,1 \mathrm{~N}$ atau natrium hidroksida 0,1 N. Tambahkan fenolftalein dan titrasi dengan kalium hidroksida $0,1 \mathrm{~N}$ atau natrium hidroksida 0,1 $\mathrm{N}$ sampai larutan berwarna merah muda lemah yang tetap setelah dikocok selama 30 detik.

Hitung kadar asam lemak bebas (dihitung terhadap asam arakidonat).

$$
\% \text { Kadar Asam Lemak Bebas }=\frac{\mathrm{MxVxT}}{10 \mathrm{~W}}
$$

$\mathrm{M}=$ Bobot Molekul Asam Lemak (Asam Arakidonat)

$\mathrm{V}=$ Volume $\mathrm{NaOH}$ yang diperlukan dalam penitaran dalam (ml)

$\mathrm{T}=$ Normalitas $\mathrm{NaOH}$

$\mathrm{W}=$ Bobot contoh dalam gram

\section{Penentuan Kadar Skualen (SNI 01-4499-1998)}

Sampel minyak ditimbang tepat 1 gr ke dalam labu alas bulat. Kemudian ditambahkan $10 \mathrm{ml} \mathrm{KOH}$ Etanol $2 \mathrm{~N}$, pasang ke kondensor di atas selubung pemanas dan panaskan selama $1 \mathrm{jam}$. Setelah pemanasan selesai (sebelum dingin) cabut kondensor dan bilas sisa sisa lemak pada kondensor dengan $\mathrm{H} 2 \mathrm{O} 8 \mathrm{ml}$ dan dietil eter $5 \mathrm{ml}$. Selanjutnya pindahkan isi labu alas bulat ke dalam corong pisah, bilas labu alas bulat dengan dietil eter pelan-pelan (jumlah total $20 \mathrm{ml}$ ). Kemudian tutup dan kocok kuat-kuat,diamkan hingga terjadi pemisahan dua fase (apabila masih terlihat seperti emulsi, kurangi suasana yang basa tersebut dengan menambahkan beberapa tetes $\mathrm{NaCl}$ jenuh) dan kocok kuat-kuat hingga terjadi pemisahan (pencucian I). Lapisan sabun (bagian bawah) dipindahkan kedalam labu alas bulat semula dan bahan tak tersabunkan (bagian atas) ke dalam corong pemisah lain yang berisi $8 \mathrm{ml} \mathrm{H} 2 \mathrm{O}$. Larutan sabun diekstrak dengan 20 $\mathrm{ml}$ diethyl eter sebanyak 2 kali lagi hasil ini adalah pencucian II dan III. Bahan tak tersabunkan yang diperoleh dari pencucian I, II dan III dicuci dengan $10 \mathrm{ml} \mathrm{H} 2 \mathrm{O}$, tutup dan kocok kuat-kuat sampai terjadi pemisahan dua fase, buang bagian bawah $(\mathrm{H} 2 \mathrm{O})$ dan cuci bagian atas dengan $50 \mathrm{ml} \mathrm{H} 2 \mathrm{O}$ lagi sebanyak 3 kali. Bahan tak tersabunkan dicuci dengan $8 \mathrm{ml} \mathrm{KOH}$ encer 0,5 $\mathrm{N}$ tutup dan kocok kuat-kuat dan dilakukan pencucian ini sebanyak 2 kali. Kemudian cuci lagi dengan $\mathrm{H} 2 \mathrm{O}$ berulang-ulang sampai air pencucian terakhir tidak memberikan warna merah muda apabila ditetesi indikator PP 1\%. Labu alas bulat bersih yang telah dikeringkan (dalam oven) ditimbang dan dimasukkan bahan tak tersabunkan hasil pencucian ke dalam labu alas bulat yang telah ditimbang dan uapkan 
(evaporasi) sampai semua dietil eter habis menguap. Semprotkan gas nitrogen ke dalam labu alas bulat sampai tidak tercium bau dietil eter lagi. Selanjutnya dimasukkan labu alas bulat ke dalam oven pada suhu $80^{\circ} \mathrm{C}$ selama 15 menit kemudian didinginkan di dalam desikator dan ditimbang.

Perhitungan \% Skualen $=\frac{A-B}{C} X 0,8 X 100$

\author{
$\mathrm{A}=$ Berat labu dan isi \\ $\mathrm{B}=$ Berat labu kosong \\ $\mathrm{C}=$ Berat contoh \\ $0,8=$ Ketetapan kadar squalen dalam bahan \\ tak tersabunkan
}

\section{Verifikasi Metode}

Verifikasi metode penetapan kadar skualen dengan cara ekstraksi meliputi akurasi dan presisi. Akurasi dan presisi dilakukan terhadap baku pembanding skualen dengan konsentrasi 97 \%. Presisi dilakukan sebanyak 6 kali kemudian dihitung koefisien variasi atau standar deviasi relatif (RSD). Akurasi dilakukan dengan membandingkan hasil penetapan kadar skualen dengan cara ekstraksi dengan kadar baku pembanding skualen (97\%).

\section{HASIL DAN PEMBAHASAN}

\section{Uji Sensoris}

Uji sensoris melibatkan 30 panelis non standar yang memenuhi persyaratan sesuai SNI 2346:2011. Sampel dimasukkan ke dalam tabung reaksi kemudian diberi kode minimal 5 digit. Selanjutnya panelis akan menilai sesuai parameter mutu yang diujikan yaitu kekeruhan, warna dan bau. Panelis dalam uji sensoris bertindak sebagai alat atau instrumen untuk mengukur mutu secara subjektif berdasarkan rangsangan yang diterima oleh panelis. Parameter mutu yang diujikan merupakan rangsangan yang dapat diindra yang bersifat fisis (kekeruhan dan warna) dan bersifat kimia (bau).

Interval nilai sensoris dihasilkan dari nilai rata-rata 30 panelis dalam menilai 3 spesifikasi yaitu kekeruhan, warna dan bau. Persyaratan nilai minimal uji sensoris untuk minyak hati ikan cucut botol adalah 7. Pada Tabel 1 hampir semua memenuhi persyaratan yaitu sampel KMHICB 1,2,3,5 dan 6 kecuali sampel 4 yang memiliki nilai akhir 6,5. Nilai sensoris ini menggambarkan penerimaan konsumen terhadap produk minyak hati ikan cucut botol, semakin tinggi nilai sensoris maka semakin tinggi penerimaan konsumen. Nilai sensoris ini dapat dijelaskan secara lebih rinci untuk masing-masing spesifikasi dalam Tabel 2.

Tabel 1. Interval nilai sensoris sampel

\begin{tabular}{lll}
\hline Kode Sampel & Interval Nilai Sensoris/Organoleptik & Penulisan Nilai Akhir \\
\hline KMHICB 1 & $7,44 \leq \mu \leq 8,12$ & 7 \\
KMHICB 2 & $7,89 \leq \mu \leq 8,37$ & 8 \\
KMHICB 3 & $7,00 \leq \mu \leq 7,89$ & 7 \\
KMHICB 4 & $6,49 \leq \mu \leq 7,15$ & 6,5 \\
KMHICB 5 & $7,89 \leq \mu \leq 8,46$ & 8 \\
KMHICB 6 & $6,90 \leq \mu \leq 7,58$ & 7 \\
\hline
\end{tabular}

Tabel 2. Nilai rerata uji sensoris sampel

\begin{tabular}{lllllll}
\hline \multirow{2}{*}{ Spesifikasi } & \multirow{7}{c}{ Sampel (Rata-Rata \pm SD) (n=30) } \\
& KMHICB 1 & KMHICB 2 & KMHICB 3 & KMHICB 4 & KMHICB 5 & KMHICB 6 \\
\hline Kekeruhan & $8,47 \pm 1,04$ & $8,60 \pm 1,10$ & $7,93 \pm 1,72$ & $4,87 \pm 1,81$ & $8,73 \pm 1,01$ & $8,60 \pm 0,98$ \\
Warna & $7,47 \pm 1,01$ & $7,93 \pm 1,14$ & $8,00 \pm 1,26$ & $7,67 \pm 1,52$ & $8,53 \pm 1,01$ & $7,67 \pm 1,21$ \\
Bau & $7,40 \pm 2,59$ & $7,87 \pm 1,46$ & $6,40 \pm 2,88$ & $7,93 \pm 1,80$ & $7,27 \pm 2,15$ & $5,47 \pm 2,61$ \\
\hline
\end{tabular}

Keterangan nilai untuk masing-masing spesifikasi :

Kekeruhan : Jernih (9), Kurang Jernih (7), Agak Keruh (5), Keruh (3), Keruh Sekali (1).

Warna $\quad$ : Kuning Muda (9), Kuning Emas (7), Kuning Kemerahan (5), Coklat (3),

Coklat Kehitaman (1).

Bau : Spesifik Minyak Ikan (9), Sedikit Bau Asam (7), Bau Asam (5), Tengik (3),

Tengik dan Bau Busuk (1). 
Berdasarkan Tabel 2 pada spesifikasi kekeruhan hampir seluruh sampel mempunyai nilai rata-rata lebih dari 7 bahkan mendekati 9 yang artinya mendekati jernih. Pada sampel KMHICB 4 memiliki nilai ratarata 4,87 mendekati nilai 5 yang artinya agak keruh. Menurut Boran, et al. (2006) dalam Widiyanto, et al. (2015) perubahan kejernihan minyak dapat dipengaruhi oleh adanya produk- produk degradasi minyak maupun sisa-sisa bahan yang tertinggal di dalam minyak. Penurunan kejernihan minyak juga dapat disebabkan oleh oksidasi pigmen yang terdapat di dalam minyak. Kekeruhan dapat diatasi dengan cara diendapkan, penyaringan menggunakan kain atau dengan cara sentrifugasi.

\section{Warna}

Berdasarkan Tabel 2 pada spesifikasi warna seluruh sampel mempunyai nilai rata-rata lebih dari 7 yang artinya memiliki warna kuning emas sampai kuning muda. Warna ini disebabkan oleh pigmen karotenoid yang secara alamiah ada di dalam minyak (Strayer, 2006). Warna ini dapat berubah menjadi merah karena proses pemanasan menggunakan suhu tinggi (over heating). Warna ini juga dapat disebabkan oleh bahan baku, hal ini dapat diatasi dengan menggunakan bahan baku yang segar, bersih dan bebas dari kontaminan (Ockerman dan Basu, 2006).

\section{Bau}

Berdasarkan Tabel 2 pada spesifikasi bau sampel KMHICB 1,2,4 dan 5 mempunyai nilai rata-rata lebih dari 7 yang berada dalam rentang bau sedikit bau asam sampai bau spesifik minyak ikan. Nilai ini masih memenuhi persyaratan. Sampel KMHICB 3 dan 6 memiliki nilai rata-rata 6,4 dan 5,7 yang berada dalam rentang bau asam dan sedikit bau asam. Nilai ini termasuk rendah dan tidak disukai oleh konsumen. Bau asam sudah sangat dekat nilainya dengan bau tengik. Menurut Kusnandar (2010) pembentukan aroma tengik pada minyak atau makanan yang mengandung lemak disebabkan oleh kerusakan minyak/lemak. Kerusakan ini dapat disebabkan oleh reaksi oksidasi maupun reaksi hidrolisis.

Penilaian uji sensoris menggunakan panelis merupakan pengujian mutu pangan yang bersifat subjektif. Panelis memegang peranan yang sangat penting dalam pengujian ini. Pengujian sensoris khususnya pada parameter bau dapat dikonfirmasi dengan pengujian menggunakan instrumen untuk mengukur derajat ketengikan lemak. Namun, dalam penelitian ini hanya dilakukan uji sensoris menggunakan panelis sesuai rujukan SNI No.2730 1-2013 tentang spesifikasi minyak hati ikan cucut botol. Derajat ketengikan lemak menggambarkan kerusakan minyak yang telah terjadi.

\section{Penentuan Kadar Air}

Kadar air adalah banyaknya air yang terkandung dalam sampel minyak hati ikan cucut botol. Semakin banyak kadar air maka akan semakin menurun kualitas minyak.

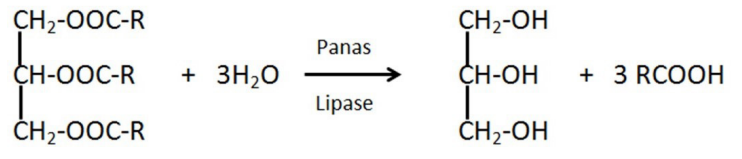

Gambar 1. Reaksi hidrolisis lemak (Kusnandar, 2010)

Penurunan kualitas minyak ini disebabkan karena air dapat mengakibatkan terjadinya reaksi hidrolisis. Reaksi hidrolisis adalah reaksi pelepasan asam lemak bebas (free fatty acid) dari gliserin dalam struktur molekul lemak atau minyak. Pelepasan satu molekul asam lemak bebas memerlukan satu molekul air. Enzim lipase dapat aktif ketika proses ekstraksi tidak menggunakan panas dan adanya air bebas yang cukup untuk beraktivitas mengkatalisis reaksi hidrolisis. Sebaliknya, ketika kadar air sedikit, maka reaksi enzimatis terhambat.

Tabel 3. Hasil penentuan kadar air sampel

\begin{tabular}{ll}
\hline Kode Sampel & $\begin{array}{l}\text { Nilai Kadar Air (\%) } \\
\text { (Rata-Rata) }(\mathbf{n}=\mathbf{2})\end{array}$ \\
\hline KMHICB 1 & $*$ \\
KMHICB 2 & 0,22 \\
KMHICB 3 & 0,1 \\
KMHICB 4 & 0,05 \\
KMHICB 5 & 0,07 \\
KMHICB 6 & 0,05 \\
\hline
\end{tabular}

*Sample mengalami kerusakan

Pada sampel KMHICB 2 sampai 6 semuanya memenuhi persyaratan SNI yaitu kadar air maksimal 0,3\%. Pada sampel KMHICB 1 tidak dapat ditentukan kadar airnya dengan metode gravimetri karena bobotnya bertambah setelah pemanasan menggunakan oven vakum sehingga tidak dapat dihitung sebagai kadar air. Penambahan bobot ini kemungkinan diakibatkan teroksidasinya asam lemak tak jenuh maupun komponen lainnya sehingga menghasilkan produk baru. Kadar air dapat dipengaruhi oleh metode ekstraksi dan suhu ekstraksi. Metode ekstraksi yang melibatkan air seperti pemanasan basah akan menyebabkan kadar air yang lebih tinggi pada ekstrak dibandingkan dengan metode yang tidak melibatkan air seperti pemanasan kering. Penggunaan suhu tinggi dalam ekstraksi dapat menurunkan kadar air; namun, juga dapat menyebabkan terpecahnya struktur minyak dan melepaskan senyawa peroksida (Ketaren, 1986). 
Metode yang dirujuk SNI untuk menentukan kadar air adalah metode gravimetri menggunakan oven vakum. Metode ini, menurut Bradley (2010) memungkinkan kesalahan yang konsisten, yaitu hilangnya senyawasenyawa volatil bersama dengan hilangnya kadar air. Senyawa volatil tersebut antara lain asam asetat, propionat, butirat, alkohol, ester dan aldehid.

Ketaren (1986) menyebut metode ini adalah metode penetapan kadar air dan zat menguap, yang dapat dilakukan dengan menggunakan hot plate, oven terbuka (air oven method) dan oven hampa udara (vaccum oven method). Bradley (2010) menyatakan bahwa metode oven vakum yang dilakukan dengan tekanan rendah (25-100 mm $\mathrm{Hg}$ ) mampu menghilangkan air dan senyawa- senyawa volatil tanpa adanya dekomposisi pada waktu 3-6 jam waktu pengeringan. Senyawa- senyawa volatil dapat ikut terhitung sebagai kadar air, sehingga perlu dilakukan faktor koreksi untuk mengkompensasi kehilangan senyawa tersebut.

SNI telah menetapkan kadar air maksimal adalah 0,3\% dengan menggunakan metode oven. Hal ini berarti bahwa SNI telah memperhitungkan juga senyawa volatil yang ikut menguap bersama air. Namun, tetap perlu dilakukan penghitungan koreksi. Metode ini mampu untuk menghitung kadar air bebas dalam minyak. Air bebas (free water) inilah yang berperan sebagai media dalam reaksi kimia (hidrolisis) dan pertumbuhan bakteri.

Metode lain yang disarankan untuk menetapkan kadar air dalam jumlah kecil adalah metode titrasi Karl Fischer. Metode ini mampu untuk mengukur kadar air total. Kadar air total terdiri dari air bebas, air terikat dan air permukaan. Pelarut yang biasa digunakan adalah metanol bebas air, minyak dalam metanol hanya larut sebagian sehingga dibutuhkan tambahan pelarut seperti kloroform. Jika di dalam sampel minyak terdapat aldehid dan keton, maka tidak dapat digunakan pelarut metanol, karena aldehid dan keton dengan metanol dapat bereaksi menjadi asetal dan ketal yang menghasilkan air. Sehingga hasil pengukuran kadar air dapat lebih besar.

\section{Penentuan Kadar Asam Lemak Bebas}

Keberadaan asam lemak bebas dalam minyak biasanya dijadikan indikator awal terjadinya kerusakan minyak karena proses hidrolisis. Reaksi hidrolisis lemak dapat terjadi baik pada lemak jenuh dan tidak jenuh. Reaksi ini dapat dipercepat oleh panas dan air (Kusnandar, 2010).
Sampel KMHICB 1 sampai 6 semuanya memenuhi persyaratan SNI kadar asam lemak bebas, yaitu maksimal 1,5\%. Berdasarkan Tabel 4 nilai kadar asam lemak bebas bervariasi mulai dari 0,19 sampai dengan 1,26. Kadar air yang tinggi dapat mempercepat reaksi hidrolisis dan pelepasan asam lemak bebas. Hal tersebut dapat terlihat pada sampel KMHICB 2 dan 3 yang memiliki kadar air tinggi $(0,21 \%$ dan $0,1 \%)$ mengakibatkan asam lemak bebasnya tinggi $(1,26$ $\%$ dan $1,21 \%$ ). Hal ini tidak terjadi pada sampel KMHICB 6 yang kadar airnya rendah 0,06 tetapi kadar asam lemak bebasnya tinggi (1,19\%). Hasil

Tabel 4. Hasil penentuan kadar asam lemak bebas sampel

\begin{tabular}{ll}
\hline Kode Sampel & $\begin{array}{l}\text { Nilai } \\
\text { Lemak Bebas (\%) } \\
\text { Rata } \pm \text { SD) }(\mathbf{n}=\mathbf{3})\end{array}$ \\
\hline KMHICB 1 & $0,19 \pm 0,01$ \\
KMHICB 2 & $1,26 \pm 0,02$ \\
KMHICB 3 & $1,21 \pm 0,05$ \\
KMHICB 4 & $0,69 \pm 0,01$ \\
KMHICB 5 & $0,33 \pm 0,03$ \\
KMHICB 6 & $1,19 \pm 0,01$ \\
\hline
\end{tabular}

ini kemungkinan karena adanya enzim lipase atau penggunaan suhu tinggi dalam ekstraksinya.

Kadar asam lemak bebas yang tinggi mengakibatkan bau tengik. Sampel KMHICB 3 dan 6 yang memiliki kadar asam lemak bebas tinggi (1,26\% dan 1,21\%) menghasilkan bau yang tidak disukai oleh panelis dengan skor 6,40 dan 5,47. Namun demikian, sampel KMHICB 2 dengan kadar asam lemak bebas tinggi $(1,17 \%)$ memiliki bau yang tetap disukai oleh panelis dengan skor 7,87. Hal ini dimungkinkan pada sampel KMHICB 2 ditambahkan zat tertentu untuk menutupi baunya.

Pembentukan asam lemak bebas akan mempercepat kerusakan oksidatif minyak. Reaksi oksidasi terjadi melalui beberapa tahap, yaitu tahap inisisasi, tahap propagasi dan terminasi. Radikal bebas yang terbentuk pada tahap inisiasi dapat bereaksi dengan oksigen dan menghasilkan senyawa peroksida. Keberadaan senyawa peroksida ini digunakan sebagai indikator terjadinya oksidasi lemak/minyak. Penentuan bilangan peroksida dapat dilakukan menggunakan metode titrimetri dengan mengukur sejumlah iod yang dibebaskan dari kalium iodida melalui reaksi oksidasi oleh senyawa peroksida di dalam pelarut asam asetat/kloroform. Iod yang dibebaskan ditentukan jumlahnya dengan $\mathrm{Na}_{2} \mathrm{~S}_{2} \mathrm{O} 3$. Semakin tinggi bilangan peroksida menunjukkan bahwa jumlah peroksida semakin banyak (Kusnandar, 2010). 
Tabel 5. Hasil pengukuran baku pembanding skualen dengan cara ekstraksi

\begin{tabular}{|c|c|c|c|}
\hline $\begin{array}{l}\text { Bobot Baku Pembanding } \\
\text { Skualen (g) }\end{array}$ & $\begin{array}{l}\text { Bobot Skualen } \\
\text { Murni }\end{array}$ & $\begin{array}{l}\text { Minyak Tak Tersabunkan } \\
\text { Dihitung Sebagai Skualen (g) }\end{array}$ & Konsentrasi (\%) \\
\hline 1,0343 & 1,0033 & 0,9369 & 93.38 \\
\hline 1,1192 & 1,0856 & 0,9911 & 91,29 \\
\hline 1,1126 & 1,0792 & 1,0064 & 93,25 \\
\hline 1,0091 & 0.9788 & 0,9159 & 93,57 \\
\hline 1,0138 & 0,9834 & 0,8973 & 91,25 \\
\hline 1,0229 & 0,9922 & 0,9149 & 92,21 \\
\hline Rata-rata & & & 92,49 \\
\hline SD & & & 1,057 \\
\hline RSD & & & 1,143 \\
\hline
\end{tabular}

Menurut Ketaren (1986), tingkat selanjutnya adalah terurainya asam-asam lemak disertai dengan konversi hidroperoksida menjadi aldehid dan keton. Bradley (2010), menyatakan bahwa adanya aldehid dapat terukur dengan bilangan paraanisidin. Menurut Kusnandar (2010), reaksi antara senyawa aldehid dengan pereaksi paraanisidin pada pelarut asam asetat akan menghasilkan warna kuning yang absorbansinya dapat diukur pada panjang gelombang $350 \mathrm{~nm}$.

\section{Penentuan Kadar Skualen Metode Ekstraksi}

Penentuan kadar skualen ditentukan sesuai metode SNI 01-4499-1998. Metode ini dilakukan dengan cara ekstraksi menggunakan pelarut dietil eter. Metode ini termasuk metode gravimetri karena analisis kuantitatif berdasarkan berat tetapnya (dilakukan dengan penimbangan). Metode ini dapat digunakan untuk semua jenis minyak. Zat-zat lemak pada minyak diubah menjadi sabun pada proses penyabunan dengan alkali etanolik. Larutan diencerkan dengan air dan bahan-bahan tak tersabunkan diekstraksi dengan dietil eter. Bahan-bahan tak tersabunkan meliputi hidrokarbon, alkohol tingkat tinggi dan sterol, khususnya untuk jenis minyak hati ikan cucut (terutama cucut dari jenis squalidae). Kemurnian ditentukan dengan penetapan kadar 80-85\% dari bahan tak tersabunkannya (SNI01-4499-1998).

Verifikasi metode gravimetri meliputi akurasi dan presisi. Verifikasi dilakukan terhadap baku pembanding skualen yang memiliki konsentrasi skualen 97\%. Metode ini menyatakan akurasi $\geq 90 \%$. Presisi dihitung menggunakan relatif standar deviasi (RSD), dengan persyaratan presisi: $\mathrm{RSD}<2^{1-0,5 \log C} \times 0,67$.

Berdasarkan Tabel 5, hasil verifikasi menunjukkan RSD 1,143 yang berarti kurang dari 1,346; sehingga dapat dinyatakan presisi. Akurasi dapat dilakukan dengan membandingkan hasil analisis dengan hasil yang telah dipublikasikan (Huber, 2007 dalam Widjanarko 2015). Hasil nilai rata-rata pengulangan ekstraksi sebanyak 6 kali adalah 92,49\% terhadap baku pembanding skualen $100 \%$. Metode ini menyatakan akurasinya $\geq 90 \%$, yaitu $92,49 \%$ sehingga memenuhi persyaratan. Setelah metode ini terverifikasi maka dilanjutkan dengan pengukuran sampel.

Tabel 6. Hasil penentuan kadar skualen sampel

\begin{tabular}{ll}
\hline Kode Sampel & $\begin{array}{l}\text { Nilai Kadar Skualen }(\%) \\
(\text { Rata-Rata } \pm \text { SD) }(\mathbf{n}=\mathbf{3})\end{array}$ \\
\hline KMHICB 1 & $12,88 \pm 0,20$ \\
KMHICB 2 & $0,68 \pm 0,36$ \\
KMHICB 3 & $0,55 \pm 0,20$ \\
KMHICB 4 & $0,35 \pm 0,10$ \\
KMHICB 5 & $39,03 \pm 1,25$ \\
KMHICB 6 & $25,59 \pm 2,38$ \\
\hline
\end{tabular}

Berdasarkan nilai pada Tabel 6 maka tidak ada satupun sampel yang memenuhi persyaratan SNI ( $\geq$ $70 \%$ ). Nilai kadar skualen pada sampel juga sangat bervariasi mulai dari 39,03\% sampai $0,35 \%$. Hall dkk., (2016) melakukan penetapan kadar skualen pada 17 minyak hati ikan cucut yang dilakukan di Selandia Baru. Minyak diperoleh dari berbagai spesies dan berasal dari berbagai tempat. Kadar skualennya bervariasi dari 0,6\% sampai 96,1\%. Jika dikaitkan dengan standar SNI maka hanya ada 6 sampel yang memenuhi syarat.

Kadar skualen dalam satu spesies pun bervariasi tergantung umur, jenis kelamin, parameter geografik dan variasi musim (Popa dkk., 2014). Dalam SNI 2730.2:2013 mengenai persyaratan bahan baku, disebutkan bahwa hati ikan cucut botol yang digunakan sebagai bahan baku berasal dari semua jenis ikan cucut botol. White dkk. (2006) menyebutkan ada beberapa spesies ikan cucut yang memiliki nama lokal cucut 
botol yaitu Centroporus squamosus, Centrophorus atromarginatus Garman, Centrophorus moluccensis, Centroporus of lusitanicus, Centrophorus niaukang Teng, Deania cf calcea, Centroporus isodon, Zameus squamulosus, Squalus sp.1, Squalus sp.3, Squalus cf sp.C dan Squalus sp.E. Pada penelitian yang dilakukan Wetherbee dan Nichols (2000) pada beberapa famili yang diantaranya adalah famili Squalidae, diperoleh hasil hanya Centroporus squamosus saja yang memenuhi syarat, yaitu $83 \%$.

Kadar skualen juga dipengaruhi oleh metode ekstraksi yang digunakan. Sunarya dkk. (1995) membandingkan 3 metode ekstraksi yaitu metode bligh and dyer, sokhleat dan steam. Hasilnya dengan metode steam diperoleh skualen yang lebih tinggi dibandingkan dengan metode bligh and dyer serta sokhleat. Metode steam menggunakan pemanasan pada suhu 70-800C selama 30 menit.

\section{KESIMPULAN}

Telah dilakukan pengujian terhadap 6 sampel kapsul minyak hati ikan cucut botol mengikuti parameter SNI No.2730.1.2013. Keseluruhan sampel tidak memenuhi persyaratan kadar skualen, namun kesemuanya memenuhi persyaratan kadar asam lemak bebas. Salah satu sampel tidak memenuhi persyaratan kadar air dan uji sensoris.

\section{UCAPAN TERIMAKASIH}

Penulis mengucapkan banyak terimakasih kepada Kemenristekdikti melalui program beasiswa afirmasi dosen magang yang telah memberikan bantuan dana dalam penelitian ini.

\section{DAFTAR ACUAN}

Keputusan Kepala Badan POM RI (2016) No.HK.00.05.52.4040 tentang Kategori Pangan, BPOM RI, Jakarta.

Anonim (2013) : Pengujian Organoleptik, Universitas Muhammadiyah Semarang, Semarang, 1-2.

Badan Standarisasi Nasional (1998) : Standar Nasional Indonesia No.01-3555-1998, Cara Uji Minyak dan Lemak, http//:websisni.bsn.go.id.

Badan Standarisasi Nasional (1998) : Standar Nasional Indonesia No.01-4499-1998, Penetapan Kadar Squalen Dengan Cara Ekstraksi, http//:websisni.bsn. go.id.
Badan Standarisasi Nasional (2006) : Standar Nasional Indonesia No.01-2354.2-2006, Cara Uji Kimia-Bagian 2 Penentuan Kadar Air Pada Produk Perikanan, http//:websisni.bsn.go.id.

Badan Standarisasi Nasional (2011) : Standar Nasional Indonesia No.2346, Petunjuk Pengujian Organoleptik dan Atau Sensori Pada Produk Perikanan. http//:websisni.bsn.go.id.

Badan Standarisasi Nasional (2013) : Standar Nasional Indonesia No.2730 1-2013, Minyak Hati Ikan Cucut Botol Mentah Bagian Spesifikasi, http//:websisni.bsn. go.id.

Badan Standarisasi Nasional (2013) : Standar Nasional Indonesia No.2730 2-2013, Minyak Hati Ikan Cucut Botol Mentah Bagian Persyaratan Bahan Baku, http//:websisni.bsn.go.id.

Badan Standarisasi Nasional (2013) : Standar Nasional Indonesia No.2730 3-2013, Minyak Hati Ikan Cucut Botol Mentah Bagian Penanganan dan Pengolahan, http//:websisni.bsn.go.id.

Boran, G., Karacam, H., dan Muhammet, B. (2006) : Changes in the quality of fish oils due to storage temperature and time, dalam Widiyanto, W. N., Ibrahim, R., dan Anggo, A. D. (2015): Pengaruh Suhu Pengolahan Dengan Metode Steam Jacket Sederhana Terhadap Kualitas Minyak Hati Ikan Pari Mondol, Jurnal Pengolahan Hasil Perikanan Indonesia, 18 (1), 11-18.

Bradley, R. L. (2010) : Moisture and Total Solids Analysis, 85-94 dalam Nielsen, S.S., (2010) :Food Analysis Fourth Edition, Springer Science and Bussines Media, New York, USA.

Debouzy, J. L., Crouzier, D., Lefebvre, B dan Dabouis, V. (2008) : Study of Alkylglycerol Containing Shark Liver Oil, Drug Target Insight, 3, 125-135.

Fahmi, Dharmadi, Sarmintohadi dan Mustika, C. (2013). A Review of the Status of Shark Fisheries and Shark Conservation in Indonesia, Directorate of Marine and Aquatic Resources Conservation, Directorate General of Marine, Coast and Small Island Ministry of Marine Affairs and Fisheries, V.

Fox, C. B. (2009): Review Skualen Emulsion for Parenteral Vaccine and Drug Delivery. Molecules, 14, 3286-3312. 
Huber, L. (2007) : Validation and Qualification in Analytical Laboratpories dalam Widjanarko, B. S., dan Megawati, J. (2015) : Analisis Metode Kolorimetri dan Gravimetri Pengukuran Kadar Glukomanan Pada Konjak (Amorphophallus Konjac). Jurnal Pangan dan Agroindustri, 3 (4), 1584-1588.

Ketaren, S. (1986) : Pengantar Teknologi Minyak dan Lemak Pangan, UI Press, Jakarta, 1-98.

Kusnandar, F. (2010) : Kimia Pangan Komponen Makro, Penerbit Dian Rakyat., Jakarta, 153-183.

Krotkiewski, M., Przbyszewska, M., dan Janik, P. (2003) : Cytostatic and Cytotoxic of Alkylglicerol (Ecomer), Medical Science Monitoring, 9(11), PI 131135.

Nurfauzi, Y., Mutriono., dan Setiabudi, A. (2014) : Identifikasi Sifat Fisika-Kimia Minyak Hati Ikan Cucut Botol Di Wilayah Perairan Cilacap, Laporan Penelitian Dosen Internal, Stikes Al- Irsyad AlIslamiyyah Cilacap.

Ockerman, H. W., dan Basu, L. (2006) : Essential Rendering, National Renderers Association,USA, 9599.

Ogawa, Y dan Doi, H. (1996) : The Use Of squalene, squalane or mixtures there of for preparing a cooling composition for the local treatment of burns, EP 0457193.

Owen, R. W., Mier, W., Giacosa, A., Hull, W. E., Spiegelhalder, B., dan Bartsch, H. (2000) : Phenolic Compounds And Squalene In Olive Oils : The Concentration and Antioxidant Potential of Total Phenols, Simple Phenols, Secoiridoids, Ligands And Squalene, dalam Gunes, F. E. (2013): Review Medical Use Of Squalene as a Natural Antioxidant, Journal of Marmara University Institut Of Health Science, 3(4), 220-228.
Pugliese, P.T., Jordan, K., Cederberg, H., dan Brohult. J. (1998) : Some Biological Actions Of Alkylglycerols From Shark Liver Oil, Journal of Alternative and Complementary Medicine, 4(1) 87-99.

Setiono, E. H. (2002) : Pemurnian Minyak Kasar Hati Ikan Cucut (Crude Shark Liver Oil) Dengan Metode Netralisasi dan Pemucatan, Skripsi Program Sarjana, Institut Pertanian Bogor.

Strayer, D., Belcher., Dawson, T., Delaney, B., Fine, J., dan Flickinger. B. (2006), Food Fats and Oil, Institute of Shortening and Edible Oils, USA, 1-6.

Wetherbee, B. M., dan Nichols, P. D. (2000) : Lipid Composition of the liver oil of deep-sea sharks from the Chatam Rise, New Zealand, Comparative Biochemistry and Phsiology Part B ,125, 511-521

White, W. T., Last, P. R., Stevens, J. D., Yearsley, G. K., Fahmi, dan Dharmadi.(2006) : Economically Important Shark and Rays Indonesia (Hiu dan Pari Yang bemilai Ekonomis penting Indonesia). CSIRO, Murdoch University, Aciar. Lamb Print, Perth, 49-73. 